\title{
Perceptions of affiliates to private pension funds
}

\section{Percepciones de afiliados a fondos de pensiones privados}

Jorge Braulio Guillen 


\title{
Perceptions of affiliates to PRIVATE Pension funds
}

\section{Percepciones de afiliados a fondos de pensiones privados}

\author{
Jorge Braulio Guillen*
}

Keywords: SEM Models, Private pension funds, Transfers.

Palabras clave: Modelos SEM, Fondos de pensiones privados, Transferencias.

IEL Classification: G23, G28, O54

Received: $15 / 10 / 2018$

Accepted: 15/05/2019

Published: 26/06/2019

\begin{abstract}
The following paper studies the determinants of choosing a private pension fund institution by processing a questionnaire of 514 affiliates. The questionnaire attempts to measure perceptions of the consumer with respect to their private pension fund institution. Using a structural equation model, we found that socioeconomic variables are irrelevant but some perceptions like the return of portfolio and leadership of the private pension fund were relevant in the choice of a private pension fund institution. We contrast the model in two different periods of time between 2009 and 2016 . The periods before and after financial turmoil in the stock market.
\end{abstract}

\section{Resumen}

El siguiente artículo estudia los determinantes de la elección de un fondo de pensiones privado, mediante el procesamiento de un cuestionario de 514 afiliados. El cuestionario intenta medir las percepciones del consumidor con respecto a sus AFPs. Usando un modelo de ecuación estructural, encontramos que las variables socioeconómicas son irrelevantes, pero algunas percepciones como el retorno de la cartera y el liderazgo del fondo de pensiones privado fueron relevantes en la elección de una institución de fondos de pensiones privada. Contrastamos el modelo en dos diferentes períodos de tiempo : 2009 y 2016. Estos son los períodos antes y después de la turbulencia internacional en el mercado de valores. 


\section{Introduction}

Private pension funds institutions are very important for economies (Barrientos, 2001; Acuña, Palomino, Villar, Villagómez, and Valero, 2014; Corbo and Schmidt-Hebbel, 2003). Domestic Savings have been influenced positively since the main purpose of these institutions is mainly ${ }^{1}$ to collect workers' contributions for retirement purposes. Retirement should reflect workers' efforts during their years of activity, so it is important to manage and get profitable returns in the retirement fund. The private pension fund system is similar to the $401 \mathrm{k}$ plan in the US. The best retirement plan will come after a significant amount of funds accumulated during the affiliate's working life.

In Chile (Kay, 2009), there is a discussion about the sustainability of the private pension fund system. There is a perception that the saving effort does not match the retirement pension. The latter perception can be captured with the replacement ratio. The replacement ratio is the percentage of precautionary retirement pension with respect to actual salary. As long as this ratio is close to $100 \%$, then it means that the affiliate is fully covered with his retirement expenses. In Chile, the retirement ratio is $30 \%$, so there is a discomfort and suspicion with respect to the efficiency of private pension funds. This ratio varies across different countries because regulations of private pension institutions are different for every single country.

Given this discomfort with respect to precautionary savings, we attempt to study the perception of the affiliate in selecting their private pension fund institution. We have processed a survey of 520 respondents. The respondents answer different questions regarding preferences with respect to private pension funds. For example, the respondent ranks in a Likert scale prestige, leadership in the market, return of portfolio, fees, service, and attention of a private pension fund institution.

Our study analyses what the main drivers are in selecting a private pension fund institution for two different periods of time: 2009 and 2016, the years before and after the volatility of the stock market and pension funds due to the subprime crisis.

During the second half of 2008, the international financial crisis created some negative effect in the region which produced some exposure in the Latin American private pension funds. Titelman, Pérez-Caldentey y Pineda (2009) verified the latter effects of the financial crisis on the region. ${ }^{2}$ Even Latin American economies slow down because of financial turmoil.

Our paper is divided as follows: the next section describes the latest reform of private pension funds, then the structural model of selecting a private pension fund is introduced, Results and conclusions area made afterwards.

\footnotetext{
1 In some countries like Mexico, we have two institutions managing pension funds: AFORES - Administradora de Fondos para el Retiro (Fundraiser for Retirement) and SIEFORES - Sociedad de Inversión Especializada en Fondos para el Retiro (Investment Company Specialized in Retirement Funds). The former collects the money from workers and the latter invests it.

2 The authors explain that compared to the previous international crisis, the effect of recent financial turmoil can be a credit crunch and fall in exports.
} 


\section{Reforms of private pension funds}

In 1980, Chile took the unprecedented step of switching from a pay-as-you-go pension system to a private pension system (fully funded). There are several countries in the region that followed the Chilean path: Peru (1993), Colombia (1993), Argentina (1994), Uruguay (1996), Bolivia and Mexico (1997), El Salvador (1998), and Costa Rica (2001). The private pension funds are mainly regulated and monitored by Superintendencia de Administradoras de Pensiones - SPPF (Superintendence of Pension Administrators) except Uruguay, where Central banks assume this role of assessment and

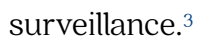

Except for Chile ${ }^{4}$, the new system coexists with the old in some countries. Therefore, Fully Funded and Pay as You Go are competing with each other (Barassi, Bertín, Musalem, 2009). In Argentina, the government took the private fund and there is no fully funded system anymore. ${ }^{5}$

The regulation of private pension funds differs across countries. Besides the establishing of the private pension system in Latin America, other countries in other regions joined the system: Australia, Eastern Europe, Hong Kong, Israel and New Zealand (Impavido, Lasagabaster, and Garcia-Huitron, 2010). The model of funding without any government participation was accepted in favor of the establishing of the system in the countries.

There is also a study ${ }^{6}$ that claimed positive effects of the private pension system in Chile and the region. However, there are some caveats and revisions that need to be fixed and done in order to improve the efficiency of the system in favor of the affiliate. The plans do not account for most of the popularity. ${ }^{7}$

The problem is that also the Pay as You Go System is not the perfect substitute to the Fully Funded mentioned above. There is a lack of credibility about pension and governance (Besley and Prat, 2005) ${ }^{8}$

In general, Impavido et al., 2010 conclude that there are problems in both systems related to market efficiency, competition regulation and the return of funds; mainly low coverage ${ }^{9}$ is still a caveat in both systems which does not allow better pensions (see Figure 1 ).

\footnotetext{
3 In Colombia, the Superintendencia Financiera (Financial Superintendence) do the control for the private pension funds.

4 In Chile Fully Funded exist alone with a solidarity pillar in order to cover the exposure of low-income families.

5 The financial crisis of 2001 in Argentina affected negatively the portfolio of the private pension fund institutions and the government took the decision to expropriate the fund and manage those. The private pension funds in Argentina concentrate their portfolio in public stocks that were affected by the 2001 Argentinian crisis (Kay, 2009).

6 Corbo and Schmidt-Hebbel (2003), Gill, Packard, and Yermo (2005), Cerda (2008) and Acuña et al. (2014).

7 See Mesa-Lago (2014) and Kay (2009) how Argentina nationalized its private retirement plan and Bolivia did the same in 2011.

8 The model by the author produces a number of predictions accounting between facts of the media industry, media capture, and political outcomes which are consistent with the countries' reality.

9 This is associated with labor frictions. The coverage problem is always linked to evasion (Queisser and Whitehouse, 2006) and informality. Higher ratios of evasion and informality bring lower coverage for the private pension funds.
} 
Figure 1. Coverage of private pension funds

Affiliates / Labor force (\%)

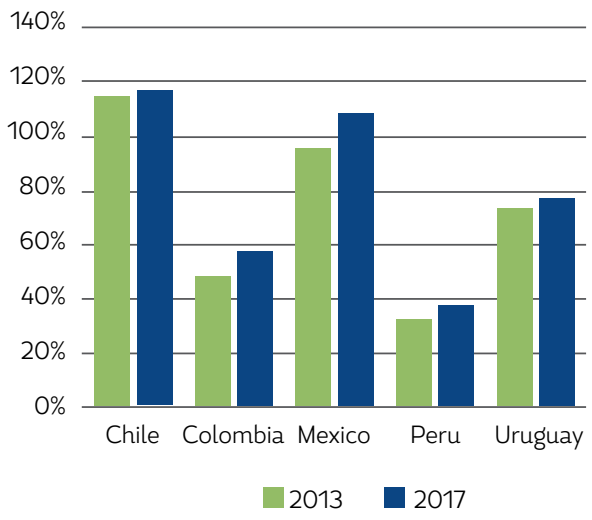

Contributors / Labor force (\%)

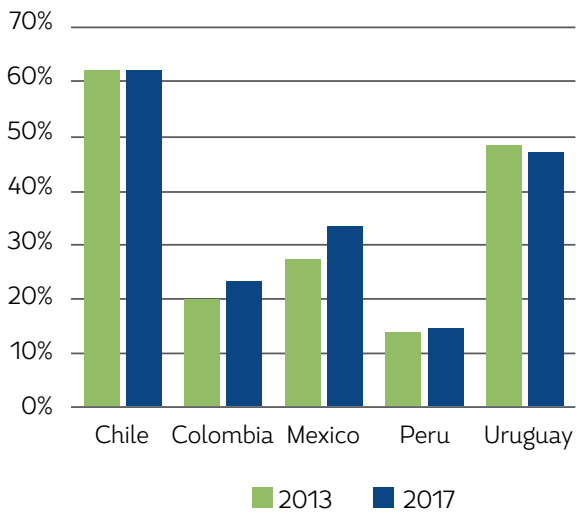

Contributors / Affiliates (\%)

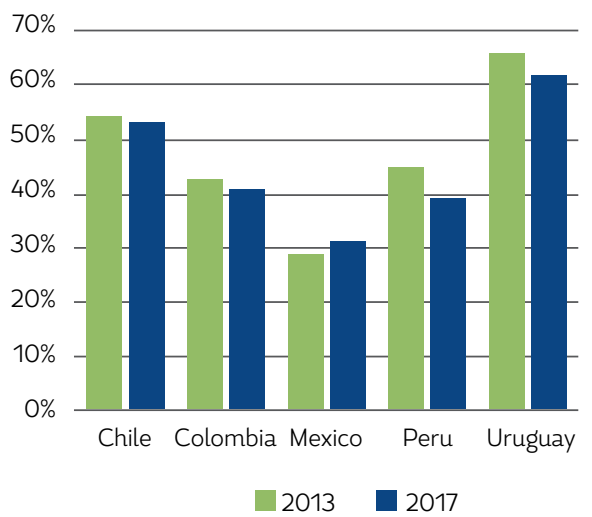

Contributors / Working* Labor force (\%)

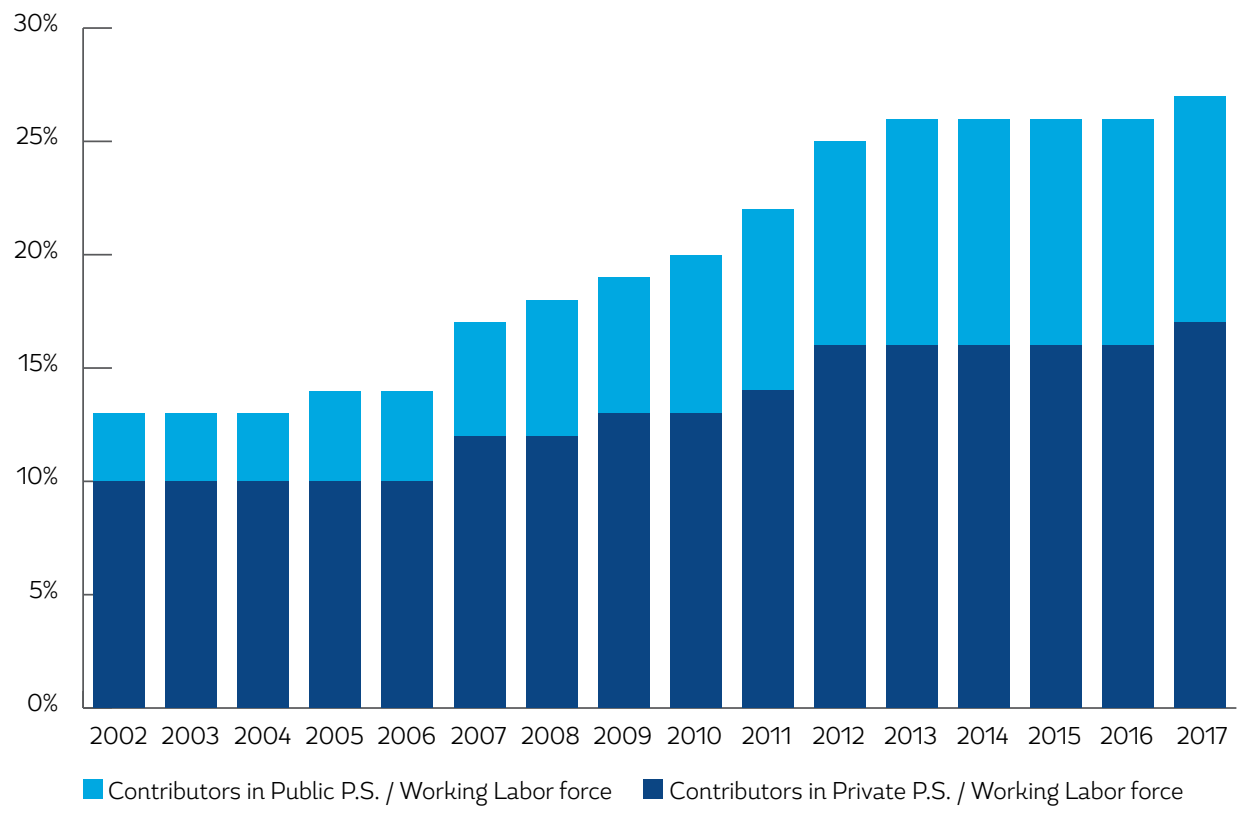

*Working labor force refers to people occupying a job. This situation happens in an informal economy, which is the case of Peru. 
We can see from the figures above that coverage is a common problem in the Latin-American Region. Coverage is measured under several ratios of Affiliates as ratio of labor force, contributors as share of labor and contributor as ratio of affiliates. As long as the ratio increases, then coverage rises.

There should be room for improvement still. In Peru, the coverage is very low, and it does not provide economies of scale may reduce fees. Melguizo, Bosh, and Pages (2015) added a contribution regarding coverage problems claim that despite perspectives of low economic growth and reduced fiscal space, the region is going through intense demographic and socio-economic changes, which increase the demand for better jobs and provide a real opportunity for initiating the bold reforms in pensions, labor, and taxes needed to achieve universal coverage.

Also, Blommestein et al. (2009) evaluated the risk of the private pension (Fully Funded) and collective system (Pay as You Go). The authors conclude that the hybrid plan seems to be more efficient than the independent plan which relies on one of the schemes. The author uses cost-benefit analysis, employing replacement (retirement salary/salary) ratio and funding ratio (asset/liability) to perform the assessment.

For Impavido et al., 2010, the indexation plan is the best in terms of risk exposure, and it is preferred by the affiliates. The ability to commit intergenerational risk sharing is also a key element that permits the preference among pensioners. The main concern for the private pension system is the downside of the stock market and the absence of acceptable protection against insolvency of the plan sponsor that guarantees benefit. Also, for the pay-as-you-go system, the concern is that young workers with a large human to financial capital may end up paying the elderly which is not optimal for this system.

The research of the pension system, either called Pay as You Go or Fully Funded, shed light on different aspects. In the literature, we would like to focus on the discussion of the consumer preferences in order to have a better form of social welfare. Therefore, to find determinants of motives to remain in the private pension system is relevant for this study, we will control for socioeconomic and demographic effects under two different periods of time: 2009 and 2016.

The survey has been conducted in Peru for a large and significant number of respondents. The questionnaire has been provided by a private institution in order to capture the preferences of affiliates with regards to their selection of a private pension institution. Most of the questions open in the discussion above will be answered in our sample study.

The next section will describe the model that allows to perform the assessment. The technique is called the Structural Equation Model (SEM), which is a method that quantifies qualitative scales. Then we can capture social welfare related to preferences of consumers with regard to their utility preference for a private pension institution.

\section{The Structural Equation Model (SEM) for affiliate's perception}

The Structural Equation Model (SEM) is an empirical technique used for business literature (Jöreskog and Sörbom, 1982). The methodology can capture relationships between qualitative variables and quantitative variables as well. SEM allows to exploit the best assessment of a survey of respondents for any decision-making after finding significant relationships that any other technique fails to explore and highlight. Recently, there have been several applications of SEM, for example, in the literature of 
tourism, Chaitip et al. (2010) run an analysis between tourist travel motivations (travel cost satisfaction and tourist demographics) and tourist destination (tourism product, tourism product attributes, and tourism product management). These latter perceptions are difficult to capture in a regular econometric perspective like Panel or Pool Data Analysis. However, SEM can assess unobservable 'latent' constructs.

The regular procedure of estimation of SEM is to run a measurement model that defines latent variables, using one or more observed variables, and then estimate a structural model that imputes relationships between latent variables. The links and estimations can be estimated under regression equations. Structural equation modeling has been widely used in the sciences, business, education, and other fields (Goldberger, 1972).

However, there are some disadvantages of SEM methods which often addresses pitfalls in a mathematical formulation, linearity or not of the relationship, weak external validity of some accepted models, subject to sampling and philosophical bias inherent in the standard procedures (see for example Westland, 2015, and MacCallum et al., 1996).

There are three models in $\mathrm{SEM}^{10}$, the first is the Path Model which is the application of structural equation modeling without latent variables. One of the advantages of this type of assessment is the inclusion of relationships among variables that are used as predictors in one single model. Figure 2 explains the latter idea.

\section{Figure 2: Path analysis-Observed variables}

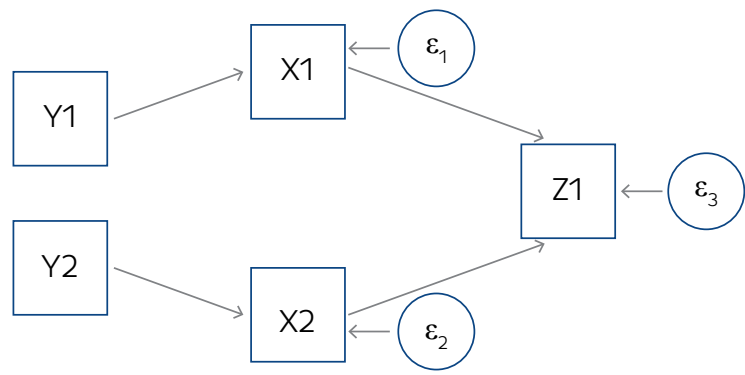

Source : Bagozzi (2012)

$\mathrm{X}, \mathrm{Y}$ and $\mathrm{Z}$ are variables related in the model

The next group of SEM model is the Confirmatory Analysis. This model estimates the paths that link each indicator to their corresponding factor o latent variables. Here we can process surveys and combine qualitative with quantitative variables as well. Confirmatory Analysis is still a bit exploratory, the confirmatory can be run the previous conception of the theoretical model the researcher has discussed previously in the literature. Figure 3 shows a simple path diagram of a two-factor CFA. 
Figure 3: Latent variable Structural Model

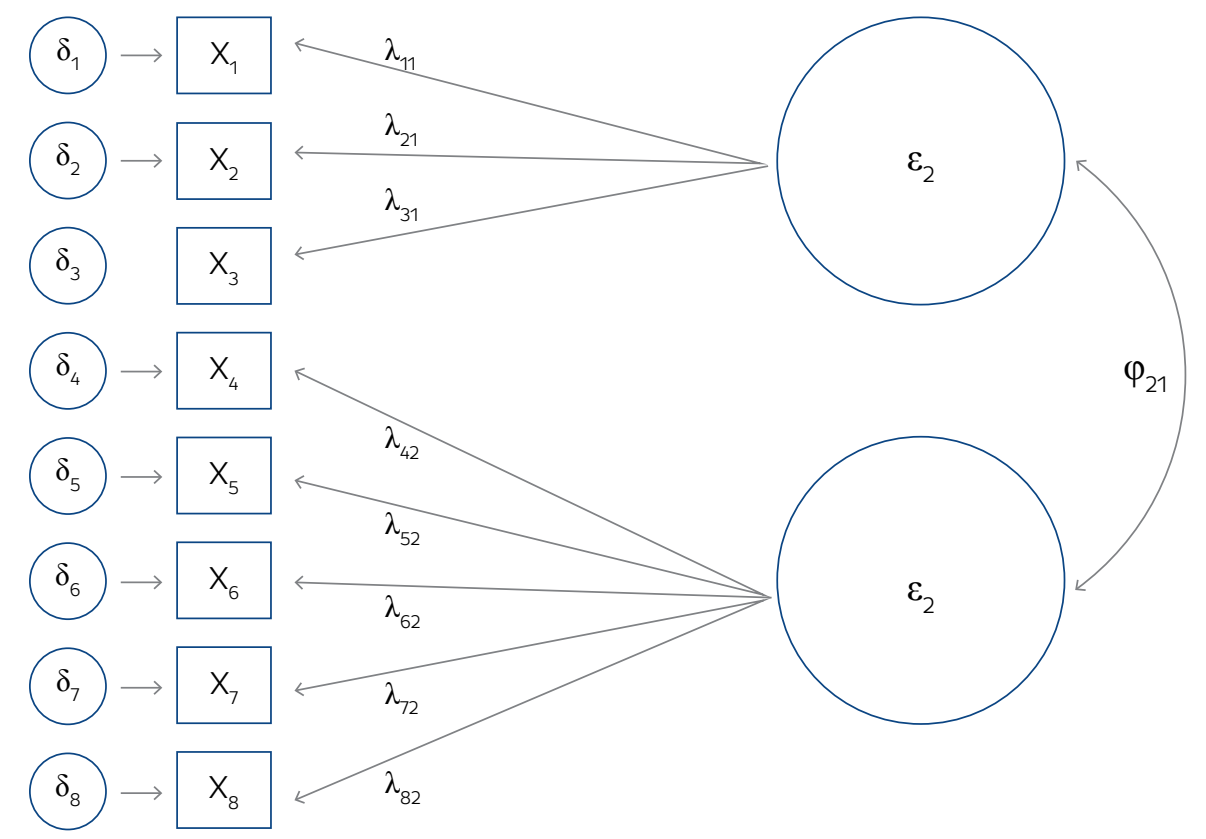

Source : Bagozzi (2012)

$\mathrm{X}_{1}$ to $\mathrm{X}_{8}$ are variables related in the model

The model below is the more accurate representation of the SEM model. It combines the measured latent variables within the path analysis framework already explained above. Once you have declared the latent variables, then we can verify the researcher hypothesis and test their relationships with this more complex model. The relationship can be as shown in Figure 4 .

\section{Figure 4: Structural Equation Model}

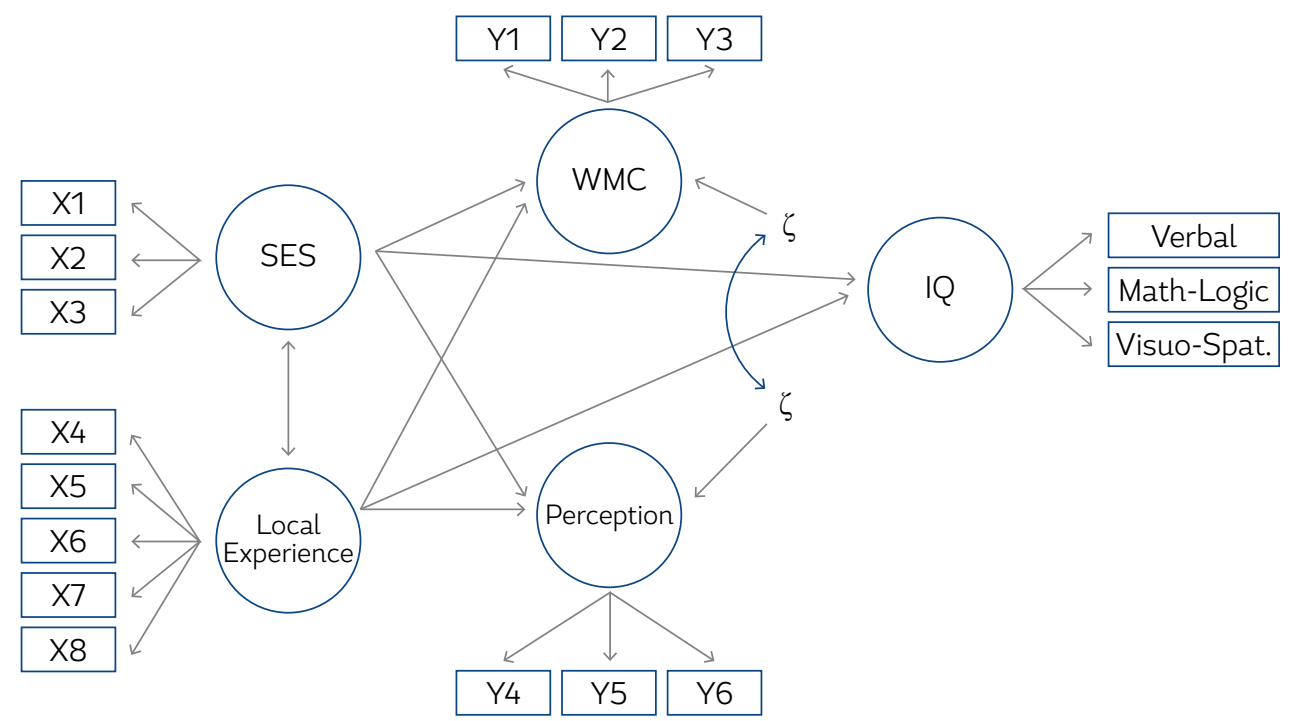

Latent Variable Structural Model 
$\mathrm{X}_{1}$ to $\mathrm{X}_{8}$ are variables related in the model, the variables SES. Local Experience, WMC and IQ and Perception are latent variables. For example IQ has its own factor variables verbal, math and Visual Spatial

There are more variations of the Model that may include moderations and double Moderations. We can mix observed and unobserved variables which are captured in a latent relationship. Also, control variables in the form of dummies can be attached for the inferential exploration.

In our paper we will analyze the relationship of the affiliate according to the Latent Variable Structural Model; socioeconomic control variables are addressed for this purpose. There is no empirical framework that has been used before in the literature of provisional studies that have accomplished such inference. Considering the privilege of a survey for the Peruvian case, we can start the exploration of the latter model in the following section. ${ }^{11}$

\section{Data analysis and model estimation of affiliate's preferences}

We employ a survey of perceptions for 804 respondents which was made in 2009. The same survey was conducted in 2016 with 513 respondents. The survey asks for questions about the perception of the affiliate with respect to their private pension Funds. Socioeconomic variables are also included in the Survey like gender, economic status, and age. We will try to explore if the latter control variables may infer in our assessment.

Perception questions to the respondents were classified in a Likert scale, they were asked to rank the relevance of prestige of their private pension fund, the leadership of the private pension fund in the system, the return of the fund, fees charged by the pension fund and the relevance of customer service. The variables were attempted to be attached in a single latent variable of perceptions, but the confirmatory analysis did not provide a significative agglomeration. ${ }^{12}$

Before estimating the structural model, we have made some estimation of correlation between latent, observed and control variables in a measurement model. We have finally ended up with the following structural model (Figure 5) to be tested in order to verify the determinants of the perception of an affiliate to their private pension fund.

Figure 5: Structural Model of affiliate's perception

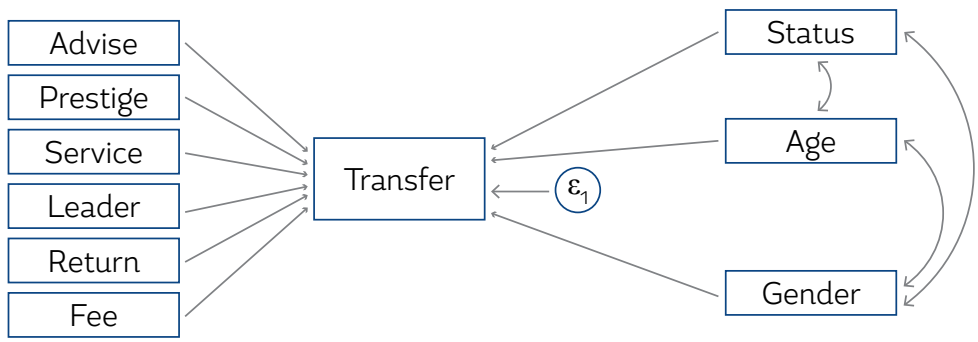

Elaboration: Own

11 Only Patrami et al. (2018) used an application of SEM to show that intention of Bogor City to pension funds in the retirement planning is influenced by subjective norms.

12 Munnell and Sundén (2001) and Ring (2005) made some relevant assessments regarding the importance of Trust in selecting a private pension. Also, Van Dalen, H. P. and Henkens, K. (2018). mentioned the importance of freedom of choice for precautionary savings 
Figure 5 shows the Theoretical Structural Model to be estimated later. Socioeconomic variables like social status, age and gender are included as control variables in the model. The variable transfer captures the preference of the affiliate to change his private pension fund. The socioeconomic variables may influence the decision to switch to a different precautionary system provider. There should be some correlation between the variables which is captured under SEM methodology.

Finally, we have included several variables of affiliate's perceptions like the importance of receiving advice, the leadership of the system, the return of portfolio, fees ${ }^{13}$ and the prestige of the private pension system. We may expect the sign of these perception variables to be negative, if the affiliate considers the perception variables as relevant, then it may reduce the probability of changing the private pension fund.

We can infer what the main variables are that affect the affiliate's decision to select a private pension fund. The next section will include the estimation and results to the model specified above.

\section{Model results for two different periods of time}

The results are split for two samples, one for 2009 and the other for the most recent event in 2016. The estimation for the two periods of time permits us to see any structural change after the financial turmoil of 2009. The financial crisis may have some impact in willingness to invest and affiliate perceptions (Antolín and Stewart, 2009). ${ }^{14}$

The figure and table below summarize the results for 2009, the period of financial turmoil in the stock markets. The variables here were not significant, there is no single determinant to the affiliate. Socioeconomic variables of control, as well as affiliates' perceptions, are not significant. The financial turmoil may have triggered some unreliability on the precautionary savings system. The result goes along the lines of some previous findings discussed above in Titelman et al. (2009). There is a concern about the sustainability of the system (Mesa-Lago, 2014) which is activated during the period of global stock market volatility. Figures 6 and 7 show the result for 2009 and 2016 periods.

Figure 6: Affiliate's perceptions in 2009

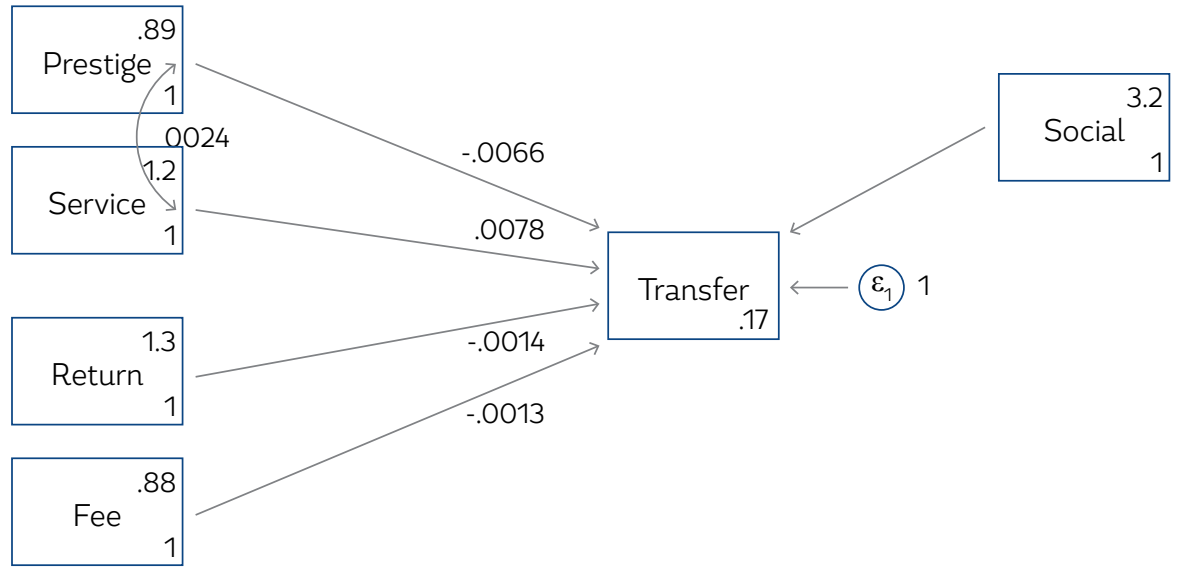


Figure 7: Affiliate's perception in 2016

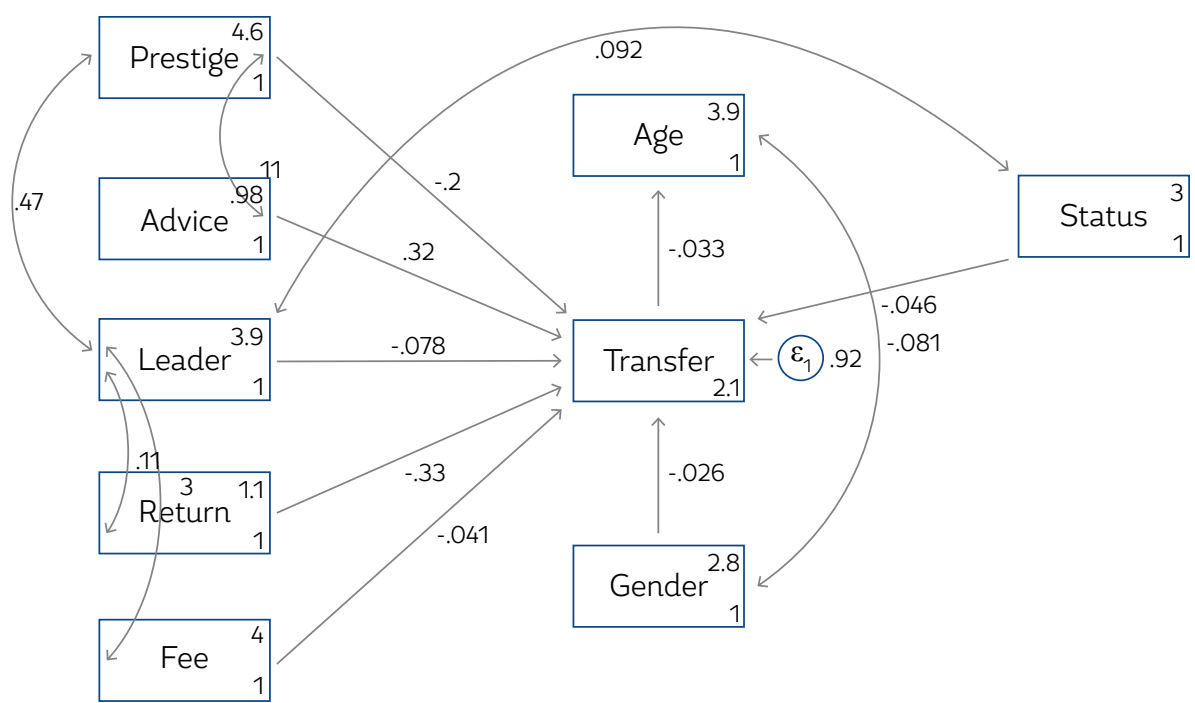

Elaboration: Own

Table 1: Structural Model for affiliate perceptions (2009)

\begin{tabular}{|c|c|c|c|c|c|c|c|}
\hline \multicolumn{8}{|c|}{ Dependent variable: Transfer } \\
\hline Variables & Coef & Std. err. & z & $P>|z|$ & & \multicolumn{2}{|c|}{ [95\% Conf] } \\
\hline \multicolumn{8}{|l|}{$\begin{array}{l}\text { Structural } \\
\text { transfer }\end{array}$} \\
\hline Service & 0.0077781 & 0.0352675 & 0.22 & 0.825 & & -0.0613450 & 0.0769012 \\
\hline Return & -0.0014365 & 0.0493286 & -0.03 & 0.077 & $*$ & -0.0981188 & 0.0952458 \\
\hline Fee & -0.0013346 & 0.0493094 & -0.03 & 0.978 & & -0.0979792 & 0.0953101 \\
\hline Prestige & -0.0065741 & 0.0352817 & -0.19 & 0.852 & & -0.0757250 & 0.0625768 \\
\hline Social status & 0.0346319 & 0.0352769 & 0.98 & 0.326 & & -0.0345096 & 0.1037733 \\
\hline _Cons & 0.1731633 & 0.1376432 & 1.26 & 0.208 & & -0.0966124 & 0.4429389 \\
\hline Observations & 803 & & & & & & \\
\hline \multicolumn{8}{|c|}{$\begin{array}{l}\text { LR test of model vs. Saturated: } \operatorname{chi} 2(0)=0.00, \\
\text { Prob> chi2 }=.\end{array}$} \\
\hline *** Significant at $1 \%$ & ** Significant a & *Significant & & & & & \\
\hline
\end{tabular}


Table 2:

\begin{tabular}{l|c}
\multicolumn{1}{c}{ Statistic } & Value \\
Likelihood ratio \\
\hline chi2_bs(5) & 1.059 \\
\hline prchi2 & 0.958 \\
\hline \multicolumn{2}{|c}{ Baseline comparison } \\
\hline CFI & 1.000 \\
\hline TLI & 1.000 \\
\hline Size of residuals & \\
\hline CD & 0.079 \\
\hline SRMR & 0.001 \\
\hline
\end{tabular}

Source:

Table 3: Structural Model for affiliate perceptions (2016)

\begin{tabular}{l|c|c|c|c|c|c|c|c}
\multicolumn{1}{c|}{$\begin{array}{c}\text { Variables } \\
\text { Structural transfer }\end{array}$} & Std. err. & $z$ & P $|z|$ & & \multicolumn{1}{c}{ [95\% Conf] } \\
\hline Age & -0.0327194 & 0.0429781 & -0.76 & 0.446 & & -0.1169548 & 0.051516 \\
\hline Advise & 0.3159606 & 0.2036847 & 1.55 & 0.121 & & -0.0832541 & 0.7151753 \\
\hline Leader & -0.077877 & 0.0488471 & -1.62 & 0.100 & $*$ & -0.1736155 & 0.0178615 \\
\hline Return & -0.3267833 & 0.2036817 & 1.6 & 0.109 & & -0.725992 & 0.0724255 \\
\hline Fee & -0.0413271 & 0.0478005 & -0.86 & 0.387 & & -0.1350144 & 0.0523602 \\
\hline Prestige & -0.1990706 & 0.0505995 & -3.93 & 0.000 & $* * *$ & -0.2982438 & -0.0998973 \\
\hline Social status & -0.0455993 & 0.0431336 & -1.06 & 0.290 & & -0.1301395 & 0.0389409 \\
\hline Gender & -0.0264457 & 0.0429762 & -0.62 & 0.538 & & -0.1106776 & 0.0577862 \\
\hline _Cons & 2.06346 & 0.3386918 & 6.09 & 0.000 & $* * *$ & 1.399636 & 2.727283 \\
\hline Observations & & & 510 & & &
\end{tabular}

LR test of model vs. Saturated: $\operatorname{chi} 2(0)=0.00$, Prob $>$ chi2 $=$.

*** Significant at $1 \%$ ** Significant at 5\% * Significant at 10\%

Source: Own elaboration.

Table 4:

\begin{tabular}{l|c}
\multicolumn{1}{c}{ Statistic } \\
Likelihood ratio \\
\hline chi2_bs(5) & 41.904 \\
\hline prchi2 & 0.000 \\
\hline \multicolumn{2}{|c}{ Baseline comparison } \\
\hline CFI & 1.000 \\
\hline TLI & 1.000 \\
\hline Size of residuals & \\
\hline CD & 0.070 \\
\hline SRMR & 0.000 \\
\hline
\end{tabular}


For 2016, the result differs from the period of financial turmoil. The perception variables of leadership and prestige were relevant in the decision of switching a private pension fund. As long as the affiliate considers the leadership of his private pension fund relevant, then his decision to change private pension fund drops. The same results are for the perception variable prestige, if the affiliate considers the private pension fund prestige relevant, then he is very unlikely to switch to another private provider of precautionary savings.

The variable advice had the opposite expected sign, but it was not significant. In addition, the variable fee has the expected sign, but it did not result as significant either. Finally, the socioeconomic variable status did not result as significant.

The fee result was irrelevant. It means that the previous discussion about informality, coverage and consequent drop of fees does not necessarily affect any decision of the affiliate regarding his preference for a private pension fund. Our study attempts to look for an improvement in the welfare of the customer of precautionary savings.

Our purpose is not to predict the decision to change a private pension fund but to find the determinants of the latter decision. Our result in 2016 is consistent and fit statistics were relevant as well (see tables below). Tables 1 and 3 present the result of the SEM model for 2009 and 2016 periods. Tables 2 and 4 show the reliability of the same model for the 2009 and 2016 periods. The assessment is relevant to explore customer's loyalty in the private pension funds.

\section{Conclusions}

We have concluded that there is structural change over time in the perceptions of affiliate to private pension funds. For our two surveys conducted in 2009 and 2016, perceptions vary for the decision to change a private pension fund provider.

In 2009, there is no driver to commit a decision to change a private pension fund, neither socioeconomic variables nor preferences are relevant for the dependent variable: change a private pension fund. Financial turmoil triggered unreliability in the precautionary savings system.

For 2016, the perception variables: leadership and prestige were relevant in the decision of selecting a private pension fund. If the affiliate considers leadership of his private pension fund relevant, then his decision to change a private pension fund drops. The same results are for the perception variable prestige. If the affiliate considers the private pension fund prestige relevant, then he is very unlikely to switch to another private provider of precautionary savings.

Our results are relevant for marketing purposes in the process of capturing new affiliates. Once we know which preference is relevant in the affiliate, then we can assign resources in the internal firm in order to enhance these relevant preferences to get more affiliates for the firm. Market segmentation made by our control variables: gender and social status were not relevant in the preference for a private pension fund provider. 


\section{References}

Asociación Internacional de Organismos de Supervisión de Fondos de Pensiones (AIOS). Database.

Acuña, R., Palomino, M., Villar, L., Villagómez, A., and Valero, D. (2014). Cómo fortalecer los sistemas de pensiones latinoamericanos. Experiencias, lecciones y propuestas Tomo II. Chile: Sura Asset Management. Available at https://www.integra.com.pe/wps/wcm/connect/www.integra.com.pe12298/485e857b737a-42fc-97a3-653e7d06e7d8/Estudio-de-Pensiones-2014-Tomo-II.pdf?MOD=AJPERES\&CONVERT_TO=url\&CACHEID=485e857b-737a-42fc-97a3-653e7d06e7d8

Antolín, P., Stewart, F. (April 2009). Private pensions and policy responses to the Financial and Economic Crisis. OECD Working Papers on Insurance and Private Pensions (36): 1-37. Available at http://www.oecd. org/finance/private-pensions/42601323.pdf

Bagozzi, R. P. and Yi, Y. (2012). Specification, evaluation, and interpretation of structural equation models. Journal of the Academy of Marketing Science, 40(1), 8-34.

Barassi, M., Bertín, H., and Musalem, A. (October 2009). Modalidades previsionales en los regímenes de capitalización de América Latina. Asociación Internacional de Organismos de Supervisión de Fondos de Pensiones, AIOS. Available at file:///C:/Users/hdiaz/Downloads/Modalidades_previsionales_America_Latina.pdf

Barrientos, A. (2001). The efficiency of pension fund managers in Latin America. Working Paper. University of Manchester.

Bentler, P. M., and Bonett, D. G. (1980). Significance tests and goodness of fit in the analysis of covariance structures. Psychological Bulletin, 88(3), 588-606.

Besley, T. and Prat, A. (March 2005). Credible pensions. Fiscal Studies, 26(1): 119-135. Available at https:// onlinelibrary.wiley.com/doi/pdf/10.1111/j.1475-5890.2005.00006.x

Blommestein, H., Janssen P., Kortleve N., and Yermo, J. (2009). Evaluating the design of private pension plans: costs and benefits of risk-sharing. OECD Working Papers on Insurance and Private Pensions (34). Available at https://www.oecd.org/finance/private-pensions/42469395.pdf

Cerda, R. (2008). The Chilean pension reform: a model to follow? Journal of Policy Modeling, 30(3), 541-558.

Chaitip, P., Chaiboonsri, C., Kovacs, S., and Balogh, P. (2010). A Structural Equation Model: Greece's tourism demand for tourist destination. Applied Studies in Agribusiness and Commerce, (4). Available at http:// ageconsearch.umn.edu/bitstream/91116/2/11_Prasert\%20A\%20Structural_Apstract.pdf

Corbo, V. and Schmidt-Hebbel, K. (May 2003). Macroeconomic effects of pension reform in Chile. Estudio presentado en la Conferencia de la Federación Internacional de Asociaciones de Pensiones: Pension Reforms: Results and Challenges, Cancún, México.

Gill, I. S., Packard, T., and Yermo, J. (2005). Keeping the Promise of Social Security in Latin America. Palo Alto, CA: Stanford University Press; Washington, DC: World Bank.

Goldberger, A. S. (1972). Structural equation models in the social sciences. Econometrica, 40(6), 979- 1001.

Impavido, G., Lasagabaster, E., and Garcia-Huitron, M. (2010). New policies for mandatory defined contribution pensions: industrial organization models and investment products. Washington: World Bank. Available at https://openknowledge.worldbank.org/handle/10986/2462 License: CC BY 3.0 IGO."

Jöreskog, K. G. and Sörbom, D. (1982). Recent developments in Structural Equation Modeling. Journal of Marketing Research, 19(4): 404-416. Available at http://www.jstor.org/stable/3151714

Kay, S. I. (July 2009). Political risk and pension privatization: the case of Argentina (1994-2008). International Social Security Review, 62(3):1-21. Available at https://onlinelibrary.wiley.com/doi/abs/10.1111/j.1468246X.2009.01335.x

MacCallum, R. C., Browne, M. W., and Sugawara, H. M. (1996). Power analysis and determination of sample size for covariance structural modeling. Psychological Methods, 1(2):130-149. http://dx.doi.org/10.1037/1082989X.1.2.130

Mesa-Lago, C. (2014). Reversing pension privatization: The experience of Argentina, Bolivia, Chile and Hungary. Geneva, ILO, ESS. (Working Paper № 44, pp. 32). 
Melguizo A., Bosh M., Pages C. (2015) Better pensions, better jobs: status and alternatives toward universal pension coverage in Latin America and the Caribbean. Journal of Pension, Economics and Finance. Volume 16, Issue 2 pp. 121-143

Munnell, A. H. and Sundén, A. (2001). What determines 401(K) participation and contributions. Social Security Bulletin, 64: 64.

Pratami, P., Suharjo, B., and Nugrahani, E. (2018). Intention model analysis of Bogor Society against Pension Fund in retirement planning. International Journal of Managerial Studies and Research (IIMSR) Volume 6, Issue 9, September 2018, pp. 15-30.

Queisser, M. and E.R. Whitehouse (2006), "Neutral or Fair? Actuarial Concepts and Pension-System Design", OECD Social, Employment and Migration Working Paper No. 40, OECD, Paris

Ring, P. I. (2005). Trust in UK pensions policy: a different approach? Policy and Politics, 33(1): 55-74.

Titelman, D., Pérez-Caldentey, E., and Pineda, R. (August 2009). ¿Cómo algo tan pequeño terminó siendo algo tan grande? Revista Cepal, (98),7-34. Available at https://repositorio.cepal.org/bitstream/handle/11362/37403/RVE98_es.pdf?sequence=1\&isAllowed=y

Van Dalen, H. P. and Henkens, K. (2018). Do people really want freedom of choice? Assessing preferences of pension holders. Social Policy \& Administration. Volume 52, Issue 7.

Westland, J. C. (2015). Structural Equation Modeling: from paths to networks. New York: Springer. 